\title{
Anatase as an alternative application for preventing biodeterioration of mortars: Evaluation and comparison with other biocides
}

\author{
Ana Josina Fonseca ${ }^{\mathrm{a}, *}$, Fernando Pina ${ }^{\mathrm{b}}$, Maria Filomena Macedo ${ }^{\mathrm{c}}$, Nuno Leal ${ }^{\mathrm{d}}$, \\ Anna Romanowska-Deskins ${ }^{\mathrm{e}}$, Leonila Laiz ${ }^{\mathrm{e}}$, Antonio Gómez-Bolea ${ }^{\mathrm{f}}$, Cesareo Saiz-Jimenez ${ }^{\mathrm{e}}$ \\ ${ }^{a}$ Departamento de Conservação e Restauro, Faculdade de Ciências e Tecnologia, Universidade Nova de Lisboa, Monte da Caparica, 2829-516 Caparica, Portugal \\ ${ }^{\mathrm{b}}$ Departamento de Química, Faculdade de Ciências e Tecnologia, Universidade Nova de Lisboa, Monte da Caparica, 2829-516 Caparica, Portugal \\ ${ }^{\mathrm{C}}$ VICARTE, Departamento de Conservação e Restauro, Faculdade de Ciências e Tecnologia, Universidade Nova de Lisboa, Monte da Caparica, 2829-516 Caparica, Portugal \\ ${ }^{\mathrm{d}}$ Centro de Investigação em Ciência e Engenharia Geológica, Faculdade de Ciências e Tecnologia, Universidade Nova de Lisboa (CICEGe-FCT/UNL), \\ Monte da Caparica, 2829-516 Caparica, Portugal \\ e Instituto de Recursos Naturales y Agrobiologia, CSIC, Av. Reina Mercedes 10, 41012 Sevilla, Spain \\ ${ }^{\mathrm{f}}$ Departamento de Biologia Vegetal, Facultad de Biologia, Universidad de Barcelona, 08028 Barcelona, Spain
}

\section{A R T I C L E I N F O}

\section{Article history:}

Received 29 October 2009

Received in revised form

12 April 2010

Accepted 19 April 2010

Available online 18 May 2010

\section{Keywords:}

Biodeterioration

Mortars

Photocatalysis

Anatase

Biocides

\begin{abstract}
A B S T R A C T
The aim of this study is the comparison between different treatments (anatase and two conventional biocides: Biotin $\mathrm{T}$ and Anios) for preventing biodeterioration of mortars. The treatments were applied both in the laboratory on mortar slabs and in situ on walls of Palácio Nacional da Pena (Sintra, Portugal). Mortar slabs treated with anatase (pure and $\mathrm{Fe}^{3+}$ doped) applied as a coating or by mixing within the mortar were prepared, and their surfaces characterized by different methodologies. The mortars were inoculated with cyanobacteria and chlorophyta species, incubated for a period of 4 months and the chlorophyll content quantified by extraction method and fluorescence emission. For comparison purposes untreated mortar slabs were inoculated, incubated and finally treated with the biocides. After two weeks the respective chlorophyll contents was quantified.

In situ studies in two external walls of Palácio Nacional da Pena covered by organisms were also performed by direct application of aqueous solutions of the three products, and the efficiency of the treatment monitored by spectrophotometry using the CIELAB method. Lichens and other phototrophic microorganisms were identified by direct observation with a microscope and cyanobacteria, green microalgae, bacteria and fungi by DNA-based molecular analysis targeting the $16 \mathrm{~S}$ and $18 \mathrm{~S}$ ribosomal RNA genes.

The results show that anatase is a better agent for preventing biodeterioration than the two ted conventional biocides, both in mortars slabs and in situ studies. In fact, photographic and colorimetric records made in two external walls of Palácio Nacional da Pena after two weeks of treatments application showed that lichens and other phototrophic microorganisms disappear from the places where anatase was applied.
\end{abstract}

(c) 2010 Elsevier Ltd. All rights reserved.

\footnotetext{
In this research photocatalytic applications were studied, for the first time, as an alternative method to biocides for the prevention and elimination of the bioderma growing on mortars located in cultural heritage buildings. The authors found out that the treatment with titanium dioxide is more effective in the prevention and elimination of microorganisms growing on mortars than the conventional biocides. Titanium dioxide is a non-toxic product that offers an excellent protective coating. Therefore, titanium dioxide is a good alternative to biocides treatment.

* Corresponding author. Tel./fax: +351212948322.

E-mail address: ana.josina.fonseca@gmail.com (A.J. Fonseca).
}

\section{Introduction}

Of all building materials for construction, artificial ones, like mortars, are the most widely used. Biological decay of mortars is a serious problem, as approximately $30 \%$ of visible alteration on building materials is due to microbial impact (Kurth, 2008). Effects of microorganisms on building facades are responsible for aesthetic, biogeophysical and biogeochemical deterioration (SaizJimenez, 1999). Due to their photoautotrophic nature, photosynthetic microorganisms, like algae and cyanobacteria, are the pioneering colonizers of building facades, and therefore, the main responsible organisms for a further biological colonization (Tomaselli et al., 2000). The cost of cleaning and treatment 
microbial deterioration on buildings is often difficult to estimate. It includes cleaning and repairing procedures, as well as cultural losses due to structural damages, which have been reviewed by Chen and Blume (2002). Thus, the development of successful conservation treatments capable of preventing and inhibiting biodeterioration, rather than the improvement of already existing biocides, is a very important issue in the cultural heritage buildings preservation context. Moreover, the identification of the microorganisms colonizing building materials can give very essential information for the research of new methods capable of avoiding the biodeterioration process.

Procedures for preventing biodeterioration include intervention methods. Chemical methods, like the use of biocides, are frequently applied as a conservation treatment for historic monuments (Caneva et al., 1996; Nugari and Salvadori, 2003). Recently, however, the use of biocides is not being well accepted, as these products do not promote a long term protection, (most frequently due to the development of resistance mechanisms by microorganisms and also rain water washing), and therefore need to be repeatedly applied (Russel and Chopra, 1990). Besides the shorttime durability of biocides treatment, the application of these products involves other sort of problems as they are toxic and can induce environmental and public health harms (Tiano, 1998). Therefore, new scientific concepts of ecological treatments are needed.

In this investigation, heterogeneous photocatalysis of $\mathrm{TiO}_{2}$, in the form of nanocrystalline anatase, was used to develop selfcleaning materials that can be applied in cultural heritage building materials.

The incorporation of photocatalysts to construction materials (cement, mortars, exterior tiles, glass) confers anti-microbial and self-cleaning properties, involving no harm to the environment (Maury Ramirez et al., 2010). Promotion of these properties is due to the photocatalytic process that occurs on the surface of the semiconductor. This process is illustrated in Fig. 1.

Once UV light is absorbed ( $\mathrm{E} \geq \mathrm{E}_{\text {bandgap }}$ ) promotion of electrons $\left(e^{-}\right)$from the valence band to the conduction band occurs, leaving back positive valence band holes $\left(h^{+}\right)$(Kelerher et al., 2002; Fu et al., 2005). One of the main paths of this charge carriers $\left(e^{-} / h^{+}\right)$ is established on the surface of the semi-conductor lattice, where redox reactions occur with some molecules present in the atmosphere (Fu et al., 2005). The following equations illustrate the photocatalytic process, responsible for the degradation of organic matter:

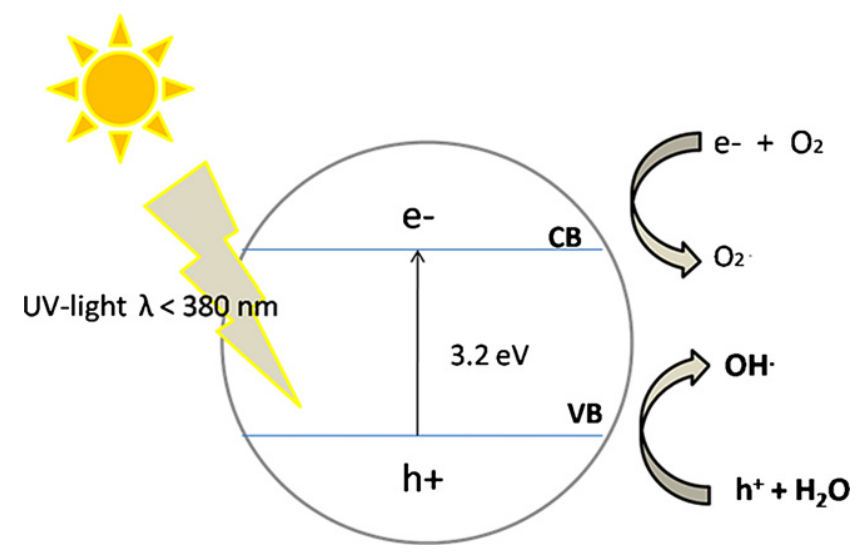

Fig. 1. Schematic illustration of $\mathrm{TiO}_{2}$ electronic structure characterized by its valence (VB) and conduction band (CB) energy positions (adapted from Kelerher et al., 2002).
$\mathrm{TiO}_{2}+\mathrm{h} u \rightarrow \mathrm{TiO}_{2}+\mathrm{e}^{-}+\mathrm{h}^{+}$

$\mathrm{e}^{-}+\mathrm{O}_{2} \rightarrow \mathrm{O}_{2}{ }^{-}$

$\mathrm{h}^{+}+\mathrm{H}_{2} \mathrm{O} \rightarrow \mathrm{HO} \cdot+\mathrm{H}^{+}$

$\mathrm{HO} \bullet+$ organic matter $\rightarrow \mathrm{xCO}_{2}+\mathrm{yH}_{2} \mathrm{O}$

Due to its high redox potencial and band gap $\left(\mathrm{E}^{\circ}=2.8 \mathrm{~V}\right.$; $E_{\text {gap }}=3.2 \mathrm{eV}$ ), the anatase variety of titanium dioxide, in the form of nanocrystalline powder, is one of the most widely used semiconductors for photocatalysis processes. The fact that this compound is non-toxic, very photoactive, photoestable, and produces colourless films when applied to materials, is a benefit (Diamanti et al., 2008; Chen and Poon, 2009). Therefore the idea of applying anatase $\left(\mathrm{TiO}_{2}\right)$ on/in building materials, as an alternative to the use of conventional biocides, is a promising approach that will be developed in this investigation.

\section{Materials and methods}

\subsection{Selection of treatments}

Three treatments were selected. Two conventional biocides, Biotin $T^{\circledR}$ (C.T.S España), frequently used in cleaning interventions on monuments, and Anios D.D.S.H® (Laboratories Anios), a biocide used as an antiseptical product for hospital procedures. The first one is a commercial biocide that has alkyl-benzyl-dimethyl-ammonium chloride and isopropyl alcohol as the active principle. The second product is a mixture of n,n-didecyl-n-methyl-poly(oxyethyl) ammonium propionate with alkyl-propylene-diamineguanidium acetate.

As an alternative product to biocides, anatase photocatalyst (P25 obtained from Degussa; predominantly nanocrystalline anatase with specific surface area of $50 \mathrm{~m}^{2} \mathrm{~g}^{-1}$ and a particle size approximately $20 \mathrm{~nm}$ ) was selected. Additionally, in order to test, in laboratory, the improvement of photocatalytic efficiency, $\mathrm{Fe}^{3+}$ doped anatase $(0.5 \mathrm{wt} \%)$ particles were prepared by wet impregnation of pure anatase on a solution of $\mathrm{Fe}\left(\mathrm{NO}_{3}\right)_{3} \cdot 9 \mathrm{H}_{2} \mathrm{O}$ (Sigma Aldrich $^{\circledR}$ ) and fired at $500{ }^{\circ} \mathrm{C}$.

\subsection{Application of the treatments}

In order to evaluate the anti-microbial effect of the three products previously selected, the experimental work described below was performed following two different lines: one, in which the products were directly applied on mortar covered walls of the Palácio Nacional da Pena (Sintra, Portugal); and other in which the products were applied in mortar samples manufactured in laboratory, following the same composition of the previously mentioned walls mortars. These are mixed binders mortars that some authors (Silva, 2002; Pereira, 2008) consider most suitable for coating walls. The mortars followed the composition of the renders used on the Palácio Nacional da Pena.

Laboratory experiments were made first, and then the in situ treatments were applied.

\subsubsection{Laboratory experiments}

Two kinds of mortars slabs were manufactured in the laboratory ( $A C$ and $A Q z$ ). Both were composed of two mixed binders (cement and lime), with the same composition ratio, but with different kinds of sand. 
The mortars were manufactured using Portland cement, (CEM II/B-L 32,5 R), high calcium hydroxide (Ridel-de Haen 31219) and sand. The mortar AC was prepared using a non-washed yellow river sand, extracted from the sandpit of Corroios, similar to the one used in Palácio da Pena, while the mortar $\mathbf{A Q z}$ was prepared with washed quartz sand $\left(\mathrm{SiO}_{2}>96 \%\right)$, since silica $\left(\mathrm{SiO}_{2}\right)$ is considered to be a very efficient support for anatase application due to its high superficial area (Chen, 2005).

Fig. 2 shows the two kinds of mortars manufactured. The cement: lime: sand proportion was $1: 4: 12$ by volume, respectively. All mortars were executed using wood casts $(4.5 \times 2 \times 2 \mathrm{~cm})$. After 7 days the mortar slabs were removed from the casts, and left curing in a room at $20 \pm 2{ }^{\circ} \mathrm{C}$ and $50 \pm 5 \% \mathrm{RH}$, during 50 days.

During the manufacturing process of the mortars, the anatase treatment was applied, following two different methodologies:

On the first one, nanocrystalline anatase powder was applied by direct addition during the manufacturing process of the mortar, at the following proportion, by volume: 12:4:4:1 - sand: lime: anatase: Portland cement.

The second methodology was done having in mind the improvement of the photocatalytic efficiency of the mortars. Therefore an application of iron-doped anatase, containing $\mathrm{Fe}^{+3}$ at $0.5 \mathrm{wt} \%$, was prepared (Návio et al., 2008). After fired at $500{ }^{\circ} \mathrm{C}$, the product obtained, $\mathrm{Fe}-\mathrm{TiO}_{2}$, was applied on the mortars slabs by the same proportion of the previous methodology: 12:4:4:1 - sand: lime: $\mathrm{Fe}$-anatase: Portland cement.

Fig. 3 illustrates a scheme of the application methodology of the treatments on the mortars slabs. This scheme shows untreated mortars sets, anatase-containing mortars sets and iron-doped anatase-containing mortars sets. After the treatments applied, all mortars were sterilized and placed, in triplicate (in order to assure representative results), inside closed Petri glass dishes $(\varnothing 15 \mathrm{~cm})$ with water on the bottom. Afterwards they were inoculated with a photosynthetic culture and incubated on an exterior terrace.

In all mortar slabs, chlorophyll a (Chla) values were quantified after inoculation and after the four months period of incubation in order to evaluate the biological growth.

Afterwards the untreated mortars slabs were then treated with the two biocides: Anios and Biotin T.

Anios was applied without any dilution and Biotin was applied diluted at $2 \%(\mathrm{v} / \mathrm{v})$ in distilled water. After 2 weeks, the effect of the application of the biocides was evaluated by chlorophyll $a$ quantification techniques.

\subsubsection{Inoculation}

In order to evaluate the anti-microbial effect of the treatments, the mortars slabs were inoculated with a mixed culture of photosynthetic microorganisms: two green microalga, Stichococcus bacillaris and Chlorella ellipsoidea, and one cyanobacterium, Gleocapsa dermochroa in BG-11 liquid culture medium. These photosynthetic microorganisms were selected, because they occur very frequently on stone monuments in European countries of the Mediterranean Basin (Miller et al., 2006; Macedo et al., 2009). All mortars were inoculated with $100 \mu \mathrm{l}$ of each culture. After inoculation, the mortars slabs were incubated at an exterior terrace, exposed to natural conditions, during 4 months (January, 23rd-May, 23rd, 2009). Moisture levels were maintained by adding sterile water $(10 \mathrm{ml})$, periodically, to the bottom of the Petri dishes.

\subsubsection{In situ experiments on the Palácio Nacional da Pena, (Sintra)}

In situ experiments were performed on two external walls of the Palácio Nacional da Pena, (Sintra). One of the walls is located on the Arches Yard, facing ENE, not receiving direct sunlight. This wall is extensively colonized by lichenic and algal communities and presents high humidity. The other wall is located on the D. Carlos Terrace, facing east, and receiving direct sunlight during much part of the day. Lichens are scattered distributed in this wall

Aqueous solutions of the three products (anatase and the two biocides) were applied directly on small areas $\left(50 \mathrm{~cm}^{2}\right)$ of the selected walls on D. Carlos Terrace and on the Arches Yard. These areas were chosen on the basis of homogeneity of substrate and biological growth. Biotin T was applied at $2 \%(\mathrm{v} / \mathrm{v})$ by brush. Anios was directly applied by spray, without any dilution, and Anatase, at $1 \%(\mathrm{v} / \mathrm{v})$ in distilled water, was also applied by spray.

\subsection{Anatase characterization}

The purity and crystallinity of anatase and iron-doped anatase samples were examined by Raman Spectroscopy, with a Labram Laser made by Jobin Yvon, using a 632.8-nm He-Ne ion laser as an excitation source. The laser power on the samples was $2.5 \mathrm{~mW}$.

Surface morphology of iron-doped anatase was analyzed by scanning electron microscope (SEM) with a JEOL Scanning Microscope T330A. Elementary characterization was carried out using energy dispersive X-ray analysis (EDX).

In order to understand the effect of doping anatase on light absorption, samples of pure anatase and iron-doped anatase were analyzed with a Shimadzu UV-2501PC to measure the UV-Visible diffuse reflectance of specimens, using $\mathrm{BaSO}_{4}$, as a reference sample.

\subsection{Analysis of the microbial communities present on the two external walls of Palácio Nacional da Pena}

A first survey on the walls was conducted for lichen and algal identification. These organisms represented the bulk of the biomass colonizing the walls. Representative specimens were collected and studied in the laboratory and species were identified or confirmed according to Clauzade and Roux (2002). Abundance was also taken into account. Then, microbial communities

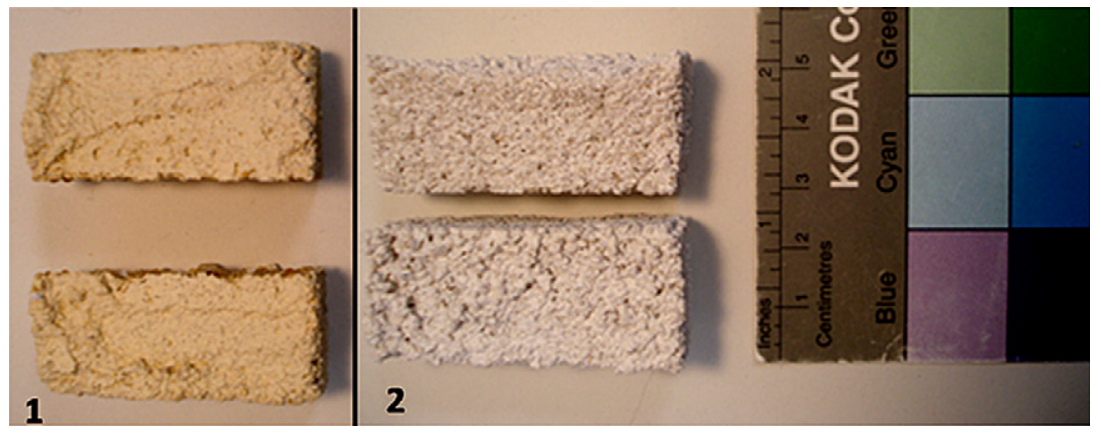

Fig. 2. Mortar slabs used for the laboratory experiments; 1) - AC mortar; 2) - AQz mortar. 


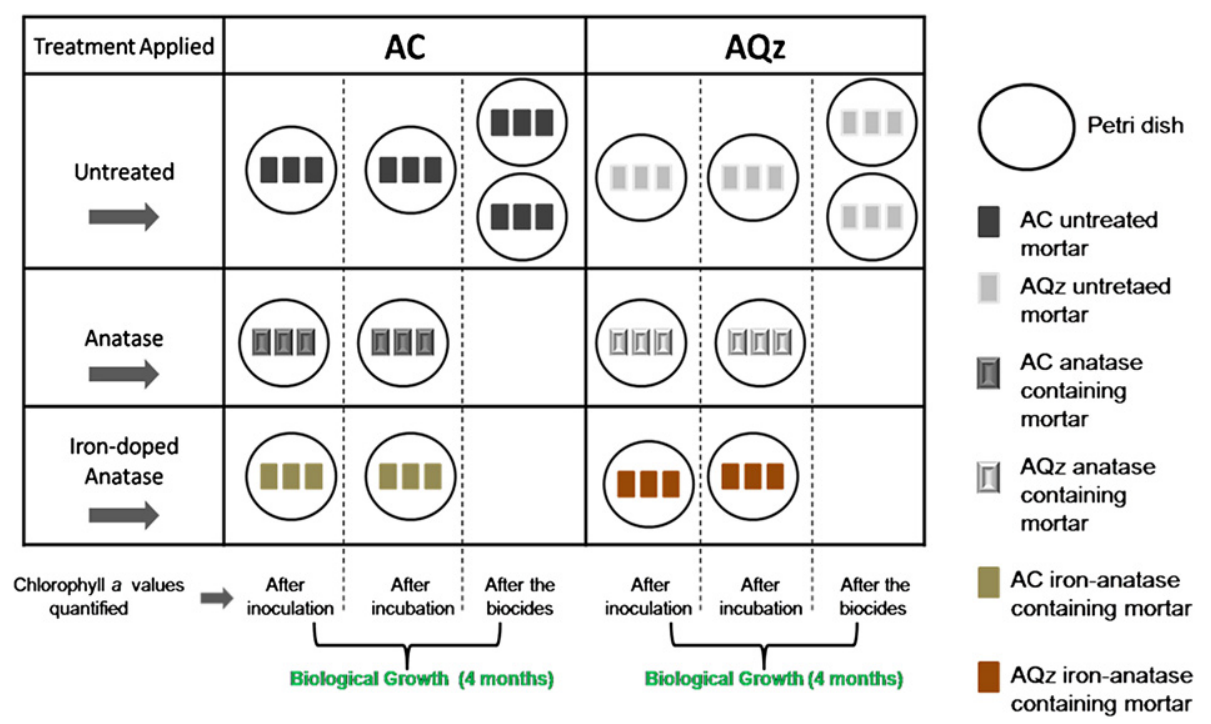

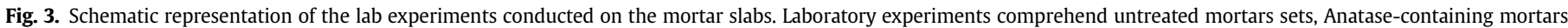
sets and iron-doped Anatase-containing mortars sets.

composed of bacteria and fungi, associated to the lichens and algae, and representing a very minor biomass moiety, were investigated using molecular tools. DNA present in the samples collected from the two external walls of the Palácio were extracted using the Nucleospin Food DNA Extraction Kit (Macherey-Nagel, Düren, Germany). The $16 \mathrm{~S}$ and $18 \mathrm{~S}$ rRNA genes were used for the identification of prokaryotes (bacteria and cyanobacteria) and eukaryotes (fungi and microalgae) respectively, as described Miller et al. (2008). Amplification of DNA was carried out by PCR and amplification products were used for two different protocols. The first analysis consisted in obtaining bacterial community fingerprints by DGGE and the second analysis was aimed to obtain 16S gene clone libraries used for sequencing as described Miller et al. (2008). Plasmids were purified using the JetQuick Plasmid Purification Spin Kit (Genomed, Löhne, Germany) and sequenced by SECUGEN Sequencing Services (CSIC, Madrid, Spain). Sequence chromatograms were edited using the software Chromas, version 2.01 (Technelysium, Tewantin, Australia). Identities searches were performed using BLAST (NationalCenter for Biotechnology Information; http://blast.ncbi.nlm.nih.gov/Blast.cgi).

\subsection{Evaluation of efficacy of the treatments}

In the laboratory experiments, evaluation of the treatments efficacy was based on the assessment of microbial growth, by quantification of chlorophyll $a$ content on the mortars slabs, relating it to the different treatments applied. Quantification of chlorophyll $a$ content was estimated by its chlorophyll $a$ fluorescence emission, using an optical fiber, and upon chlorophyll $a$ extraction method.

Three fluorescence emission measures were performed before, immediately after inoculation, and after the period of incubation, using a spectro-fluorometer (SPEX Fluorolog-3 Model FL3-22), fitted with an optical fiber (Horiva-Jove-Yvon Model F3000). The optical fiber was placed perpendicular to the mortar surface, and to assure always the same distance of irradiation, an "O-ring" was placed between the optical fiber and the mortar slab. All samples were excited at $430 \mathrm{~nm}$.

Chlorophyll a content was also quantified, immediately after inoculation and after the period of incubation, upon extraction method, using dimethyl sulfoxide (DMSO) as a solvent (Wollenweider, 1979). For both chlorophyll a quantification techniques, biologic growth ratio was calculated, meaning the ratio between after incubation chlorophyll $a$ values and after inoculation chlorophyll $a$ values.

Regarding the in situ experiments on Palácio Nacional da Pena, evaluation of efficacy of the treatments was carried out by colour measurements and photograph records before and after two weeks of application of the treatments.

Colour measurements were performed using a portable spectrophotometer (Minolta CM-508i). The results are the mean value of ten measures per area. CIELAB method was used in order to characterize the surface colour by three parameters: $L^{*}$ (lightness), $a^{*}$ and $b^{*}$ (chromatic coordinates), defined by CIE (Commission Internationale de l'Éclairage). Total colour variation $\left(\Delta E^{*}\right)$ was calculated on the same spot, as a spatial difference between two points, corresponding to the initial colour, before the treatment applied and to the colour after treatment applied:

$\Delta \mathrm{E}^{*}=\sqrt{ }\left(\Delta \mathrm{L}^{* 2}+\Delta \mathrm{a}^{* 2}+\Delta \mathrm{b}^{* 2}\right)$, being $\Delta \mathrm{L}^{*}=\mathrm{L}^{*}$ (after treatment) $-\mathrm{L}^{*}$ (before treatment); $\Delta \mathrm{a}^{*}=\mathrm{a}^{*}$ (after treatment) $-\mathrm{a}^{*}$ (before treatment); $\Delta \mathrm{b}^{*}=\mathrm{b}^{*}$ (after treatment) $-\mathrm{b}^{*}$ (before treatment).

\section{Experimental results}

\subsection{Anatase characteristics}

Pure anatase (P25-Degussa) and iron-doped anatase films show the anatase crystal phase confirmed in the Raman spectrum by five peaks at $144,197,397,518$ and $640 \mathrm{~cm}^{-1}$, originated by anatase tetragonal structure $\left(3 \mathrm{E}_{\mathrm{g}}+2 \mathrm{~B}_{1-\mathrm{g}}+1 \mathrm{~A}_{2 \mathrm{~g}}\right)$. The anatase structure is maintained upon doping with iron.

SEM image of an iron-doped anatase sample is shown in Fig. 4. In this figure is observed aggregates and discrete particles of mixed $\mathrm{Fe}-\mathrm{TiO}_{2}$ oxides. EDX analysis determined the elementary composition of the iron-doped anatase. It confirmed the presence of a $\mathrm{Fe}-\mathrm{Ti}$ phase $(\mathrm{Fe}: \mathrm{Ti}=23,63$ : 76,37 $\mathrm{wt} \%$ ), suggesting that the doping process was efficient.

The doping effect on light absorption is shown in Fig. 5. After the doping process has been completed, the colour of the sample turned from white to yellow, as the absorption of the iron-doped films shifted more to the visible region (400-700 nm), when compared with the un-doped $\mathrm{TiO}_{2}$ film. The shift to the visible 


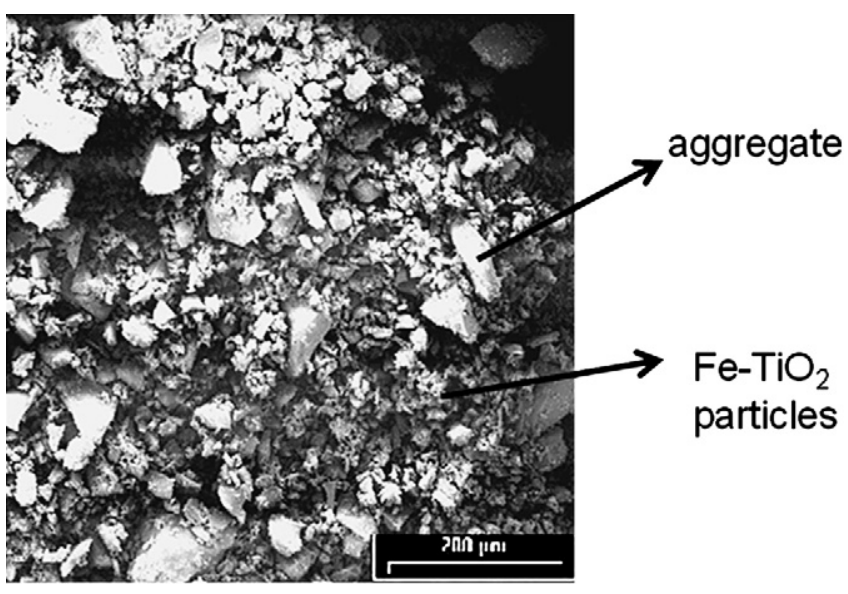

Fig. 4. SEM image of an iron-doped Anatase sample.

region of the iron-doped anatase films decreases the $\mathrm{TiO}_{2}$ band gap $\left(E_{\text {gap }}\right)$, but at the same time enhances the semi-conductor performance when activated under sunlight, since sunlight is composed of approximately $5-10 \%$ of UV light $(\lambda<390 \mathrm{~nm})$ and $45 \%$ of Visible light.

\subsection{Microbial communities present on the two external walls of Palácio Nacional da Pena}

\subsubsection{Lichen and algal communities}

The distribution of lichens and algae in Palácio Nacional da Pena is closely related to the microclimatic conditions of the walls. These are determined by the orientation of each wall, as the level of exposure to sunlight seems to be a primary factor, influencing both the likelihood of lichen colonization and the thallus type. The community present in the Arches Yard has a dark colour and covered most part of the walls. This was composed of Trentepohlia sp. as a majoritary member, followed by Opegrapha calcarea Sm., Bacidia cf. scopulicola (Nyl.) A.L.Sm., Ramalina sp., and cf. Cystocoleus

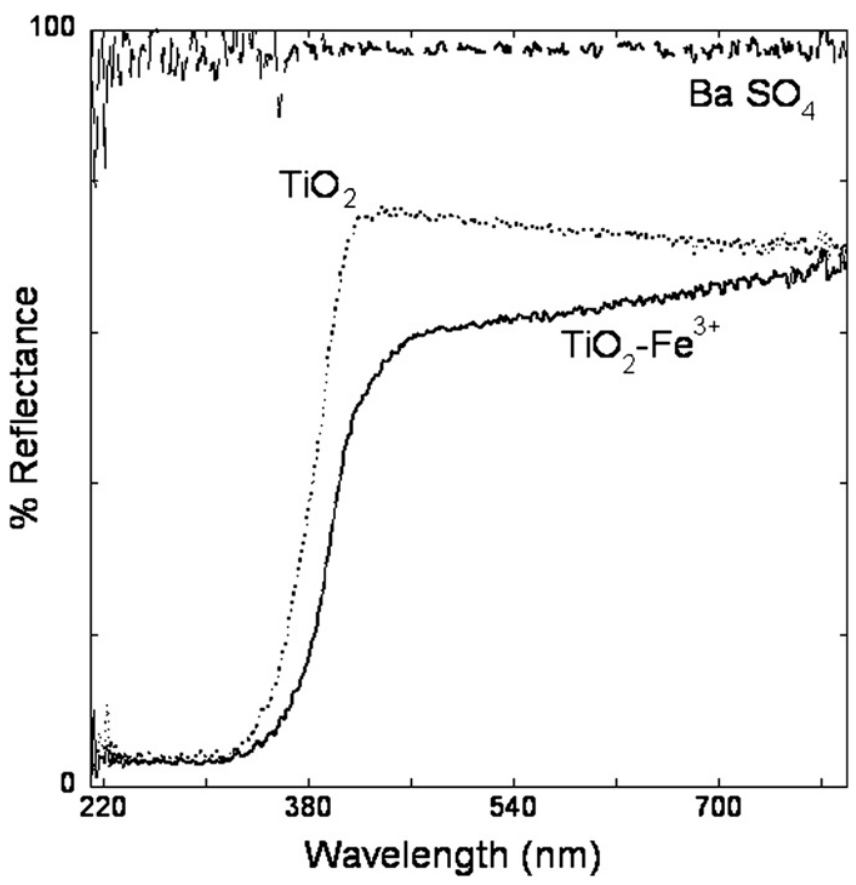

Fig. 5. Diffuse reflectance spectra of Anatase and Fe-doped Anatase films. sp. In the area protected from insolation developed O. calcarea Sm., while in the area with some more light and wind was settled Ramalina sp. Bacidia cf. scopulicola appeared close to Opegrapha calcarea, while Cystocoleus appeared in semiexposed areas, next to Ramalina sp. Trentepohlia occupy most part of the wall, no matter their exposure and water availability. The occurrence of Trentepohlia indicates a high degree of atmospheric humidity. If the atmospheric conditions are drier (for example by wind action) then lichens are dominating. In these case Cystocoleus sp., lichen that has Trentepohlia as photobiont, is the dominant. The lichenization of Trentepohlia as Cystocoleus allows these algae to colonize a new and more arid microhabitat (Chapman and Waters, 2002). In fact, the filamentous Trentepohlia is one of the most common green algae photobionts (Nash, 1996).

The wall of D. Carlos Terrace was covered by Caloplaca group citrina; Fulgensia sp.; Squamarina cf. lentigera; Toninia candida; and cf. Pyrenocollema sp. irregularly distributed as patches. In addition, the cyanobacterium Scytonema sp. and the moss Tortula sp. were found. In this terrace, the areas subjected to water run-off or soaked by water developed cf. Pyrenocollema sp., and Scytonema sp. In the exposed areas with a stable surface appeared Caloplaca group citrina. In the places with fissures, where some dust was accumulated, the presence of squamulose thalli of Fulgensia sp., Squamarina cf. lentigera, T. candida and the moss Tortula sp. were observed.

\subsubsection{Molecular biology}

The purpose of a molecular study was to know the microorganisms associated to the lichenic and algal communities. These associated microorganisms were a very minor proportion in biomass with respect to the presence of lichenic thalli and Trentepohlia filaments. Table 1 presents the algae, identified by molecular biology methods, from the two external walls of Palácio Nacional da Pena. The microalgae detected in this study were mainly Trentepohlia and other Chlorophyta. Trentepohlia occurred only in the Arches Yard. However, Chlorophyta chloroplasts appeared in D. Carlos Terrace. This is because oligonucleotide primers originally developed for the specific amplification of 16S rRNA gene segments from cyanobacteria not only targeted cyanobacterium sequences, but also sequences derived from phototrophic eukaryotes (Burja et al., 2006).

Trentepohlia can be considered a terrestrial algae and usually presents an orange or red-brown colouration (Graham and Wilcox, 2000). Regarding D. Carlos Terrace, the DNA analysis only allows us to determine Chlorophyta chloroplast, which probably belongs to lichen phycobionts

Table 2 presents the results of the prokaryotic microorganisms identified. The bacteria biodiversity is significantly higher in the Arches Yard than in D. Carlos Terrace. This can be explained by the fact that the Arches Yard wall receives less sunlight and it is usually more humid than the D. Carlos Terrace wall, which is subjected to

Table 1

Phylogenetic affiliations of algae identified in the two external walls of Palácio Nacional da Pena.

\begin{tabular}{|c|c|c|c|}
\hline Phylogenetic affiliation $^{\mathrm{a}}$ & Similarity (\%) & Primer & Location \\
\hline Trentepohlia sp. (DQ399592) & 99 & EukA-EukB & Arches Yard \\
\hline Trentepohlia sp. (DQ399592) & 98 & EukA-EukB & Arches Yard \\
\hline Trentepohlia sp. (DQ399592) & 97 & EukA-EukB & Arches Yard \\
\hline $\begin{array}{l}\text { Chlorophyta chloroplast } \\
\text { (AB374385) }\end{array}$ & 93 & 616F-1510R & D. Carlos Terrace \\
\hline $\begin{array}{l}\text { Chlorophyta chloroplast } \\
\text { (FJ028695) }\end{array}$ & 99 & $\begin{array}{l}\text { Cya 106F-Сya } \\
781 R\end{array}$ & D. Carlos Terrace \\
\hline $\begin{array}{l}\text { Chlorophyta chloroplast } \\
\text { (EU751597) }\end{array}$ & 98 & $\begin{array}{l}\text { Cya 106F-Сya } \\
781 \mathrm{R}\end{array}$ & D. Carlos Terrace \\
\hline
\end{tabular}


Table 2

Phylogenetic affiliations of prokaryotic microorganisms identified in the two external walls of Palácio Nacional da Pena.

\begin{tabular}{|c|c|c|c|}
\hline Phylogenetic affiliation $^{a}$ & Similarity (\%) & Primer & Location \\
\hline $\begin{array}{l}\text { Uncultured Cyanobacteria } \\
\text { (AJ292689) }\end{array}$ & 98 & $616 \mathrm{~F}-1510 \mathrm{R}$ & Arches Yard \\
\hline $\begin{array}{l}\text { Uncultured Cyanobacteria } \\
\quad \text { (EU621967) }\end{array}$ & 97 & $616 \mathrm{~F}-1510 \mathrm{R}$ & D. Carlos Terrace \\
\hline $\begin{array}{l}\text { Uncultured Cyanobacteria } \\
\quad \text { (FJ480240) }\end{array}$ & 94 & 616F-1510R & D. Carlos Terrace \\
\hline $\begin{array}{l}\text { Uncultured Cyanobacteria } \\
\quad \text { (EU409853) }\end{array}$ & 92 & $\begin{array}{l}\text { Cya } 106 \mathrm{~F}-\text { Cya } \\
781 \mathrm{R}\end{array}$ & D. Carlos Terrace \\
\hline Nostoc punctiforme (DQ185258) & 98 & $\begin{array}{l}\text { Cya } 106 \mathrm{~F}-\text { Сya } \\
781 \mathrm{R}\end{array}$ & D. Carlos Terrace \\
\hline Hymenobacter sp. (EU382214) & 96 & $616 \mathrm{~F}-1510 \mathrm{R}$ & Arches Yard \\
\hline $\begin{array}{l}\text { Uncultured Hymenobacter } \\
\quad \text { (AF408296) }\end{array}$ & 96 & $616 \mathrm{~F}-1510 \mathrm{R}$ & D. Carlos Terrace \\
\hline $\begin{array}{l}\text { Flexibacteraceae bacterium } \\
\quad \text { (EU155013) }\end{array}$ & 95 & 616F-1510R & Arches Yard \\
\hline Sphingomonas sp. (FJ429181) & 94 & 616F-1510R & Arches Yard \\
\hline $\begin{array}{l}\text { Uncultured Sphingomonadaceae } \\
\text { (AM697066) }\end{array}$ & 97 & $616 F-1510 R$ & Arches Yard \\
\hline $\begin{array}{l}\text { Uncultured Sphingomonadaceae } \\
\text { (AB473921) }\end{array}$ & 94 & 616F-1510R & Arches Yard \\
\hline $\begin{array}{l}\text { Uncultured Bacteroidetes } \\
\text { (FJ790565) }\end{array}$ & 93 & 616F-1510R & Arches Yard \\
\hline $\begin{array}{l}\text { Uncultured bacterium } \\
\text { (DQ532204) }\end{array}$ & 94 & 616F-1510R & Arches Yard \\
\hline
\end{tabular}

the sunlight almost all day. Also because the abundant biomass in the Arches Yard represents a better substratum than the scattered lichen colonies found in D. Carlos Terrace wall. Bacteria need high moisture values (or substratum water activity) and organic matter from exudates of lichen hyphae to develop (Chen and Blume, 2002).

Regarding Bacteria domain, biodiversity is significantly higher in the Arches Yard than in D. Carlos Terrace, as correspond to a more humid microclimate and higher organic matter availability. Members of the Sphingomonadaceae, Flexibacteraceae, Bacteroidetes and Hymenobacter were retrieved. However, the similarities of these bacteria are enough low to ascribed the sequences to a determined phylogenetic affiliation.

In Table 3 are presented the fungi identified. Most of the fungi were identified in the Arches Yard while in D. Carlos Terrace it was possible to retrieve some lichens.

\section{Evaluation of efficacy of the applied treatments}

\subsection{Laboratory experiments}

As shown in Fig. 6, fluorescence emission spectra of the mortars slabs before inoculation assure that no photosynthetic

Table 3

Phylogenetic affiliations of fungi/lichens identified in the two external walls of Palácio Nacional da Pena.

\begin{tabular}{lll}
\hline Phylogenetic affiliation $^{\text {a }}$ & Similarity (\%) & Location \\
\hline Uncultured Ascomycete (EU409872) & 97 & Arches Yard \\
Capnobotryella sp. (AJ972857) & 99 & Arches Yard \\
Cercospora sp. (AY840527) & 99 & Arches Yard \\
Mycosphaerella sp. (EU167605) & 98 & Arches Yard \\
Ramichloridium sp. (EU041798) & 97 & Arches Yard \\
Zasmidium sp. (DQ681315) & 96 & Arches Yard \\
Xanthoria elegans/parietina & 97 & D. Carlos Terrace \\
$\quad$ (AF088254/AF241541) & & \\
Caloplaca trachyphylla (DQ641412) & 90 & D. Carlos Terrace \\
\hline a Closest relatives obtained by comparison with the NCBI database. Accession \\
numbers of the closest related database entries are given between brackets.
\end{tabular}

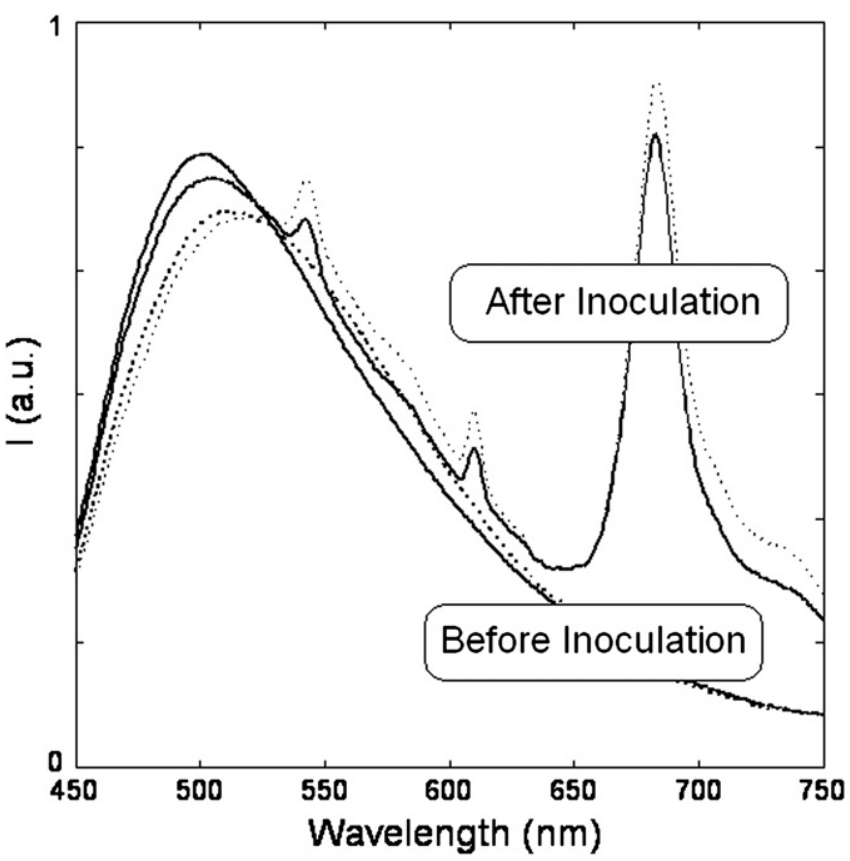

Fig. 6. Fluorescence emission spectra of the mortars slabs before and after inoculation: full line AQz mortar; traced line AC mortar. Each of these spectra is the average of all the replicates spectra.

microorganisms were present on the slabs, as no emission on the correspondent spectra region of Chla was detected $(650-700 \mathrm{~nm})$. Immediately after inoculation of the mortars slabs, fluorescence emission was once again measured. Chla is present, as a strong peak was detected at $683 \mathrm{~nm}$, proving that all mortars were inoculated with success.

After the period of incubation (4 months), fluorescence spectra and quantification of Chla concentration upon extraction method were once again measured. Quantification of chlorophyll a content techniques (spectro-fluorescence and upon extraction method) allowed the evaluation of efficacy of the treatments. However, it must be stressed that the results obtained with the extraction method and the spectro-fluorescence method give different kinds of information, as the first one allows the quantification of the chlorophyll $a$ content on the total mortars slabs volume and not just of its surface, as the spectro-fluorescence technique does. Sometimes, this fact has strong consequences on the data interpretation, as referred by Miller et al. (2010), namely when there is endolithic growth.

Tables 4 and 5 show the chlorophyll $a$ values obtained by spectro-fluorescence and by extraction method, immediately after inoculation, after incubation and after application of the biocides, for AC mortar and AQz mortar, respectively. In general, all treatments were efficient, as all treated mortars present a lower chlorophyll $a$ content than the untreated mortars for both types of mortars (Tables 4 and 5). However, the best results were obtained for the mortars slabs treated with $\mathrm{TiO}_{2}$ and Biotin $\mathrm{T}$. As observed on Tables 4 and 5, these treatments present the lowest photosynthetic growth ratio of all treatments. However, these results show that only mortars slabs treated with anatase were able to mineralize organic matter, as the chlorophyll $a$ content obtained after treatment was lower than the one estimated immediately after inoculation (Tables 4 and 5) and the growth ratio was approximately nule for $\mathrm{AC}$ and $\mathrm{AQz}$ mortars. These results prove the efficient photocatalysis power of $\mathrm{TiO}_{2}$ on the degradation of organic matter. Although the mechanism of biological inactivation is yet not very well understood, Wu et al. (2009), suggested that the anti-bacterial 
Table 4

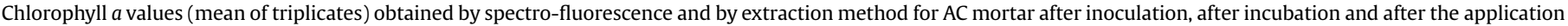
of the biocides.

\begin{tabular}{|c|c|c|c|c|c|}
\hline AC mortar & & $\begin{array}{l}\text { Spectro-Fluorescence } \\
\text { (cps at } 683 \mathrm{~nm} \text { ) }\end{array}$ & $\%$ growth ratio & $\begin{array}{l}\text { Extraction Method } \\
\text { ( } \mu \text { g Chla) }\end{array}$ & $\%$ growth ratio \\
\hline \multirow[t]{2}{*}{ Untreated } & After Inoculation & $5.6 \times 10^{5}$ & 100 & $8.9 \times 10^{-5}$ & 100 \\
\hline & After 4 months & $5.5 \times 10^{6}$ & & $3.7 \times 10^{-2}$ & \\
\hline \multirow[t]{2}{*}{ Anatase } & After Inoculation & $5.5 \times 10^{5}$ & 0 & $1.2 \times 10^{-4}$ & 0 \\
\hline & After 4 months & $7.7 \times 10^{4}$ & & $1.2 \times 10^{-4}$ & \\
\hline \multirow[t]{2}{*}{$\mathrm{Fe}$-Anatase } & After Inoculation & $5.6 \times 10^{5}$ & 11 & $5.0 \times 10^{-5}$ & 12.5 \\
\hline & After 4 months & $6.4 \times 10^{5}$ & & $2.6 \times 10^{-3}$ & \\
\hline \multirow[t]{2}{*}{ Anios D.D.S.H } & After Inoculation & $5.6 \times 10^{5}$ & 0 & $8.9 \times 10^{-5}$ & 32 \\
\hline & After 2 weeks & $1.9 \times 10^{5}$ & & $1.2 \times 10^{-2}$ & \\
\hline \multirow[t]{2}{*}{ Biotin $\mathrm{T}$} & After Inoculation & $5.6 \times 10^{5}$ & 0 & $8.9 \times 10^{-5}$ & 0.2 \\
\hline & After the 2 weeks & $7.5 \times 10^{4}$ & & $6.2 \times 10^{-5}$ & \\
\hline
\end{tabular}

$\%$ growth ratio values are always referent to the untreated slabs of each mortar. Being the growth ratio of untreated mortars a maximum value $=100 \%$.

effect of $\mathrm{TiO}_{2}$ is attributed to the destruction of the bacterial cell wall and membrane by the photocatalytic oxidation process of $\mathrm{TiO}_{2}$. There is yet a lack of data regarding the specific mechanism of cell death, however what we know is that hydroxyl radicals generated by the anatase photocatalyst are very potent oxidants that can in fact mineralize organic matter:

$\mathrm{HO} \cdot+$ organic matter $\rightarrow \mathrm{xCO}_{2}+\mathrm{yH}_{2} \mathrm{O}$

Iron-doped anatase (Fe-anatase) treatment showed good results but not as good as those estimated for pure $\mathrm{TiO}_{2}$ treatment. This may be due to an excessive addition of iron on the crystal lattice, producing large aggregates of hematite that decreased the anatase photocatalytic activity (Asilturk et al., 2009). Concerning the conventional biocides treatments, results in Tables 4 and 5 show that application of Biotin $\mathrm{T}$ was much more efficient than Anios, for both types of mortars.

Therefore the following index of efficacy of treatment (in decreasing order) is presented, on the basis of chlorophyll a content obtained by extraction method.

Anatase $>$ Biotin $\mathrm{T}>$ Anatase-Fe $>$ Anios

\subsection{In situ experiments in Palácio Nacional da Pena}

After application of treatments, chromatic changes were detected on both selected areas. Tables 6 and 7 show colour variation on D. Carlos Terrace and Arches Yard, respectively.

Total colour variation $\left(\Delta \mathrm{E}^{*}\right)$ of the different treatments applied appears to show the same pattern: application of anatase treatment appears to be more efficient than Biotin $\mathrm{T}$, and much more efficient that Anios.

Increase of $\mathrm{L}^{*}$ parameter after anatase application is more significant that the two biocides treatments. The $\mathrm{L}^{*}$ parameter is responsible for the luminosity and shining of the surface (black-white; 0/100). Therefore, increasing of the $\mathrm{L}^{*}$ parameter after the anatase treatment is due to the disappearance of dark organic matter. The increase of croma parameter $\mathrm{a}^{*}$ (green-red; $-60 /+60$ ) after anatase treatment, is also significant and is due to the decrease of green hue (corresponding to the elimination of photosynthetic microorganisms). Figs. 7 and 8 show the visual alteration of the surface after two weeks of application of the treatments on both walls. As it is possible to see in these photographs anatase and biotin aqueous solutions were the best treatments, as almost all biological growth was removed after two weeks. Anios treatment showed the worst results on both selected walls of the Palace, and therefore is not considered suitable to apply in cultural heritage for preventing biodeterioration.

\section{Discussion}

The Palácio Nacional da Pena stands on the top of a hill above the town of Sintra, surrounded by a vast forested area and is a UNESCO World Heritage. This monument constitutes one of the major expressions of 19th century Romanticism in the world. The walls of the Palace were colonized by lichens and algae and the species distribution depends on the orientation, water availability, building material, etc. The identification of the lichens was based on morphological, anatomical and chemical data and follow Clauzade and Roux (2002). However, when using molecular tools we found identities that they do not correspond exactly with the conventional identifications. This is because, apparently, database of lichens are far from complete and, therefore molecular identifications, are in some cases incorrect. Crespo and Pérez-Ortega (2009) reported that there is a lack of correlation between phylogenetic and morphological data, at least for characters normally used in lichen systematics.

Table 5

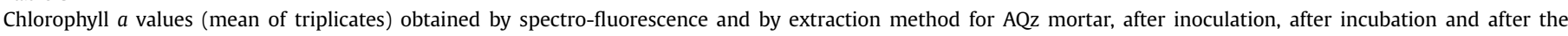
application of the biocides.

\begin{tabular}{|c|c|c|c|c|c|}
\hline AQz mortar & & $\begin{array}{l}\text { Spectro-Fluorescence } \\
\text { (cps at } 683 \mathrm{~nm} \text { ) }\end{array}$ & $\%$ growth ratio & $\begin{array}{l}\text { Extraction Method } \\
\text { ( } \mu \text { g Chla) }\end{array}$ & $\%$ growth ratio \\
\hline Untreated & $\begin{array}{l}\text { After Inoculation } \\
\text { After } 4 \text { months }\end{array}$ & $\begin{array}{l}2.6 \times 10^{5} \\
5.8 \times 10^{6}\end{array}$ & 100 & $\begin{array}{l}6.9 \times 10^{-5} \\
1.5 \times 10^{-1}\end{array}$ & 100 \\
\hline Anatase & $\begin{array}{l}\text { After Inoculation } \\
\text { After } 4 \text { months }\end{array}$ & $\begin{array}{l}8.5 \times 10^{5} \\
9.0 \times 10^{4}\end{array}$ & 0 & $\begin{array}{l}1.6 \times 10^{-4} \\
1.2 \times 10^{-4}\end{array}$ & 0.03 \\
\hline $\mathrm{Fe}$-Anatase & $\begin{array}{l}\text { After Inoculation } \\
\text { After } 4 \text { months }\end{array}$ & $\begin{array}{l}5.5 \times 10^{5} \\
4.7 \times 10^{5}\end{array}$ & 0 & $\begin{array}{l}1.1 \times 10^{-4} \\
1.1 \times 10^{-2}\end{array}$ & 4.6 \\
\hline Anios D.D.S.H & $\begin{array}{l}\text { After Inoculation } \\
\text { After the biocide }\end{array}$ & $\begin{array}{l}2.6 \times 10^{5} \\
1.1 \times 10^{6}\end{array}$ & 19 & $\begin{array}{l}6.9 \times 10^{-5} \\
2.5 \times 10^{-2}\end{array}$ & 17 \\
\hline Biotin & $\begin{array}{l}\text { After Inoculation } \\
\text { After the biocide }\end{array}$ & $\begin{array}{l}2.6 \times 10^{5} \\
1.1 \times 10^{5}\end{array}$ & 0 & $\begin{array}{l}6.9 \times 10^{-5} \\
3.4 \times 10^{-3}\end{array}$ & 2.3 \\
\hline
\end{tabular}

$\%$ growth ratio values are always referent to the untreated slabs of each mortar. Being the growth ratio of untreated mortars a maximum value $=100 \%$. 
Table 6

Colour variation measured on D. Carlos Terrace wall.

\begin{tabular}{lllll}
\hline Treatments & $\Delta \mathrm{L}^{*}$ & $\Delta \mathrm{a}^{*}$ & $\Delta \mathrm{b}^{*}$ & $\Delta \mathrm{E}^{*}$ \\
\hline Anatase & 5.36 & 5.00 & -2.57 & 7.77 \\
Biotin T & 3.26 & 3.99 & -1.67 & 5.42 \\
Anios & 0.45 & 3.16 & -1.88 & 3.70 \\
\hline
\end{tabular}

Table 7

Colour Variation measured on the Arches Yard wall.

\begin{tabular}{llllr}
\hline Treatments & \multicolumn{1}{c}{$\Delta \mathrm{L}^{*}$} & $\Delta \mathrm{a}^{*}$ & $\Delta \mathrm{b}^{*}$ & $\Delta \mathrm{E}^{*}$ \\
\hline Anatase & 10.49 & 3.31 & -5.25 & 12.19 \\
Biotin T & 6.68 & 3.08 & -2.46 & 7.76 \\
Anios & -0.59 & 1.34 & -4.86 & 5.08 \\
\hline
\end{tabular}

Although cyanobacteria appear in both walls, Nostoc punctiforme was only detected in D. Carlos Terrace. Nostoc primarily occurs in terrestrial habitats, frequently in association with fungi in lichens. This cyanobacterium is capable of fixing nitrogen directly from the air and it can transform molecular nitrogen gas into ammonia, which can then be assimilated into amino acids, proteins and other nitrogen-containing cellular constituents. This nitrogenfixation capacity allows this cyanobacterium to live under severe environmental conditions or extreme habitats. For instance, deserts and grasslands lichens are typically associated with an array of soil cyanobacteria such as Nostoc species to form desert crust consortia (Graham and Wilcox, 2000). This might explain why N. punctiforme grow well in the walls of $D$. Carlos Terrace which are dryer and receive more sun than the Arches Yard. The others cyanobacteria also appear to prefer D. Carlos Terrace, in fact, only one cyanobacteria has been found in the walls of Arches Yard. Ortega-Calvo et al. (1993) surveyed the cyanobacteria and chlorophyta colonizing the walls of Salamanca and Toledo cathedrals. They found that samples taken near ground level (the case of Arches Yard) are characterized by the absence of cyanobacteria, which were however present in places exposed to sunlight, at $50 \mathrm{~m}$ height (the case of D. Carlos Terrace). Some authors (Garcia-Pichel and Castenholz, 1993) state that many cyanobacteria can inhabit environments with intense solar radiation since they present distinct mechanisms to prevent UV photodamage among which are the negative photomovements and the synthesis of UV sunscreen compounds.

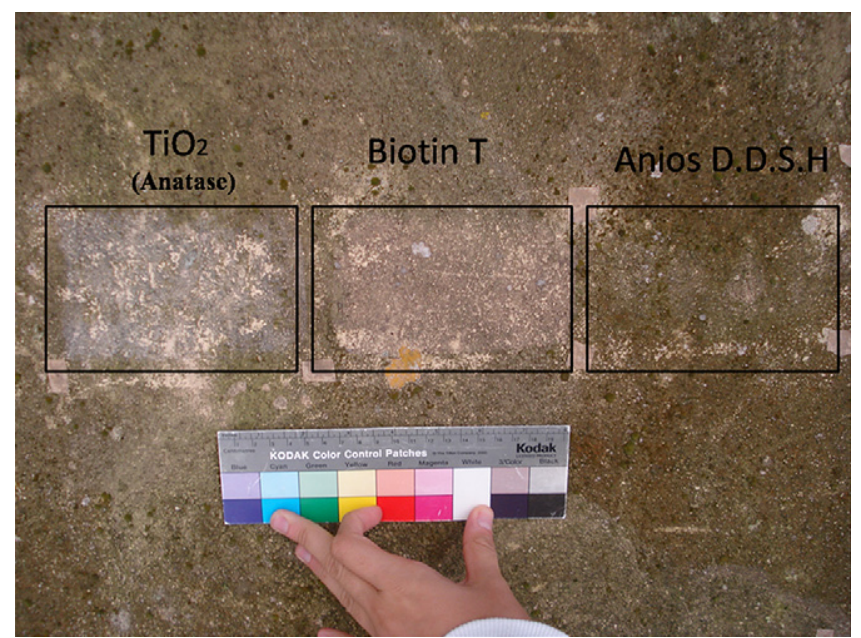

Fig. 7. Photograph of the tested areas on the arches Yard wall, after two weeks of the application of the treatments.

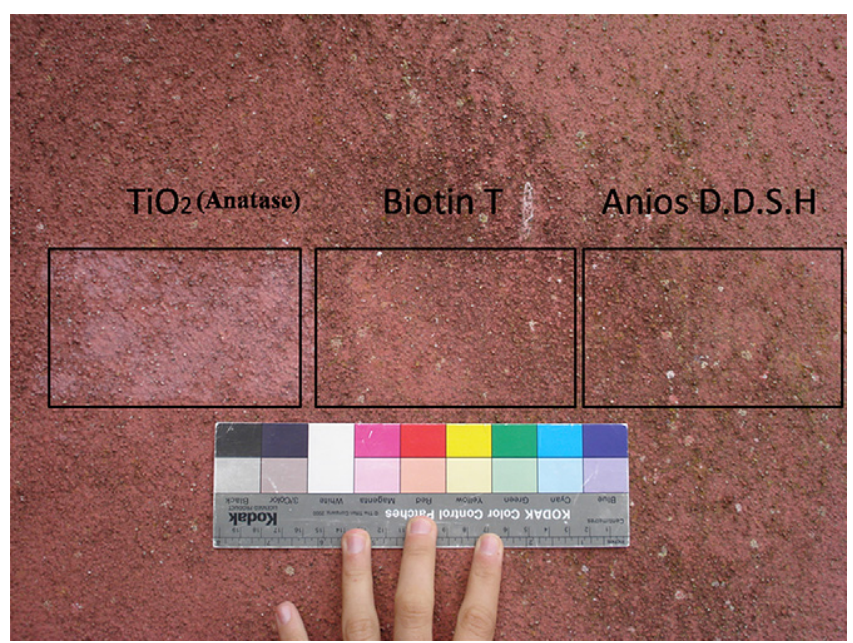

Fig. 8. Photograph of the tested areas on the D. Carlos terrace wall, after two weeks of the application of the treatments.

Among the bacteria identified, the most abundant are sphingomonads, which are widely distributed in nature, having been isolated from many different soil and water habitats, as well as from plant root systems, clinical specimens, and other polluted environments.

Some of the fungi identified were previously related with building deterioration. Recently, Sert et al. (2007) identified new species of the genus Capnobotryella on monument surfaces. Their occurrence on marble monuments is associated with aesthetical degradation due to the colour changes and black spots. Others fungi are plant pathogens, such as Mycosphaerella and Cercospora (Goodwin et al., 2001)

Concerning the experiments performed in the laboratory and in Palácio Nacional da Pena walls, both demonstrate the high efficacy of anatase treatments for preventing (and treating) biodeterioration of mortars. The use of anatase photocatalysis, on or in building materials will be able to spare financial costs for cleaning and repairing procedures, as it is a more preventive and cheaper treatment than biocides. The microorganisms present in the Palácio Nacional da Pena walls should be monitored by molecular biology methods and also by colorimetric method for at least 12 months, on a monthly basis, in order to make sure that the Anatase treatment has a long lasting effect.

However, for the lichens and mosses colonizing mortars, a previous mechanical removal can facilitate the Anatase action. We found different morphologies of lichen thalli; fruticose like in Ramalina sp., squamulose like in Squamarina sp. and crustose like Caloplaca sp. All of them have stratified thalli, with an external cortex layer constituted by hyphal cells. The cortex protect the algal layer and avoid the Anatase action on great part of the vegetative body. Furthermore, the rhizines that penetrate into the mortars are protected by the lichen thallus against Anatase and these hyphal cells, if airborne algal cells are captured, can generate a new lichen thallus. A similar process can be assumed for mosses, and rhizines can be protected in deeper mortar layers from the Anatase action.

\section{Conclusions}

Nowadays, from the conservation viewpoint it is important to control biodeterioration process with new environmentally friendly technologies. Therefore, this research allowed the authors to conclude that anatase photocatalyst is a better agent for preventing biodeterioration than the conventional biocides, conferring an excellent protective coating and self-cleaning properties to 
building materials. Moreover it is non-toxic and by consequence a good alternative to conventional biocides.

Although, it will be necessary to develop a further scientific research on anatase photocatalysis self-cleaning applications, the potential of combined nanotechnology and preventive conservation will allow a positive compromise for an environmental method of preventing biodeterioration of building materials.

\section{Acknowledgements}

The authors wish to thank Parques de Sintra - Monte da Lua for the possibility to study this beautiful monument that is Palácio Nacional da Pena. We also wish to thank the Departamento de Quimica REQUIMTE for technical and experimental support. Acknowledgements are also due to the CICEGe-FCT/UNL, for SEM-EDX facilities, and to the DCT-FCT/UNL, for the use of the terrace for external conditions experiments. This is a TCP CSD2007-00058 paper.

\section{References}

Asilturk, M., Sayilkan, F., Arpaç, E., 2009. Effect of $\mathrm{Fe}^{+3}$ dopping to $\mathrm{TiO}_{2}$ on the photocatalytic degradation of Malachite Green dye under UV and vis-irradiation. Journal of Photochemistry and Photobiology A: Chemistry 203, 64-71.

Burja, A.M., Tamagnini, P., Bustard, M.T., Wright, P.C., 2006. Identification of the green alga, Chlorella vulgaris (SDC1) using cyanobacteria derived 16S rDNA primers: targeting the chloroplast. FEMS. Microbiology Letters 202, 195-203.

Caneva, G., Nugari, M.P., Pinna, D., Salvadori, O., 1996. Il Controllo del degrado biológico - i biocidi nel restauro dei materiali lapidei. Nardini Editore, Fiesole.

Chapman, R.L., Waters, D.A., 2002. Lichenization of the Trentepohliales. In: Seckbach, J. (Ed.), Symbiosis: Mechanisms and Model Systems. Kluwer, Dordrecht, pp. 359-371.

Chen, J., Blume, H.-P., 2002. Rock-weathering by lichens in Antarctic: patterns and mechanisms. Journal of Geographical Science 12, 387-396.

Chen, J., Poon, C., 2009. Photocatalytic construction and building materials: from fundamentals to applications. Building and Environment 44, 1899-1906.

Chen, X., 2005. Synthesis and investigation of novel materials for improved photocatalysis, $\mathrm{PhD}$ thesis, Case Western Reserve University, USA.

Clauzade, G., Roux, C., 2002. Likenoj de Okcidenta Eŭropo, Traduction des clés de détermination par P. Ravel. Association Française de Lichénologie, Paris.

Crespo, A., Pérez-Ortega, S., 2009. Cryptic species and species pairs in lichens: a discussion on the relationship between molecular phylogenies and morphological characters. Anales del Jardin Botanico de Madrid 66S1, 71-81.

Diamanti, M.V., Ormellese, M., Pedeferri, M., 2008. Characterization of photocatalytic and superhydrophilic properties of mortars containing titanium dioxide. Cement and Concrete Research 38, 1349-1353.

Fu, G., Vary, P.S., Lin, C., 2005. Anatase $\mathrm{TiO}_{2}$ Nanocomposites for Antimicrobial Coatings. Journal of Physical Chemistry B 109, 8889-8898.

Garcia-Pichel, F., Castenholz, R.W., 1993. Occurrence of UV-absorbing, mycosporinelike compounds among cyanobacterial isolates and an estimate of their screening capacity. Applied and Environmental Microbiology 59, 163-169.

Goodwin, S.B., Dunkle, L.D., Zismann, V.L., 2001. Phylogenetic analysis of Cercospora and Mycosphaerella based on the internal transcribed spacer region of ribosomal DNA. Phytopathology 91, 648-658.
Graham, L.E., Wilcox, L.W., 2000. Algae. Prentice Hall, Upper Saddle River, NJ 640 pp.

Kelerher, J., Bashant, J., Heldt, N., Johnson, L., Li, Y., 2002. Photo-catalytic preparation of silver-coated $\mathrm{TiO}_{2}$ particles for antibacterial applications. Journal of Microbiology and Biotechnology 18, 133-139.

Kurth, J.C., 2008. Mitigating biofilm growth through the modification of concrete design and practice. Master thesis, Georgia Institute of Technology, USA.

Macedo, M.F., Miller, A.Z., Dionisio, A., Saiz-Jimenez, C., 2009. Biodiversity of cyanobacteria and green algae on monuments in the Mediterranean Basin: an overview. Microbiology 155, 3476-3490.

Maury Ramirez, A., Demeestere, K., Belie, N., Mantyla, T., Levanen, E., 2010. Titanium dioxide coated cementitious materials for air purifying purposes: preparation, characterization and toluene removal potential. Building and Environment 45, $832-838$.

Miller, A.Z., Dionísio, A., Macedo, M.F., 2006. Primary bioreceptivity: a comparative study of different Portuguese lithotypes. International Biodeterioration and Biodegradation 57, 136-142.

Miller, A.Z., Laiz, L., Gonzalez, J.M., Dionísio, A., Macedo, M.F., Saiz-Jimenez, C., 2008. Reproducing stone monument photosynthetic-based colonization under laboratory conditions. Science of the Total Environment 405, 278-285.

Miller, A.Z., Leal, N., Laiz, L., Rogerio-Candelera, M.A., Silva, R.J.C., Dionisio, A. Macedo, M.F., Saiz-Jimenez, C., 2010. Primary bioreceptivity of limestones used in Southern Europe monuments. In: Smith, B.J., Gomez-Heras, M., Viles, H.A. Cassar, J. (Eds.), Limestone in the Built Environment: Present Day Challenges for the Preservation of the Past. Geological Society of London, Special Publications, vol. 331, pp. 79-92.

Nash III, T.H., 1996. Lichen Biology. CambridgeUniversity Press.

Návio, J.A., Macias, M., Gárcia-Gómez, M., Pradera, M.A., 2008. Functionalisation versus mineralisation of some $\mathrm{N}$-heterocyclic compounds upon UV-illumination in the presence of un-doped and iron-doped $\mathrm{TiO}_{2}$ photocatalysts. Applied Catalysis B: Environmental 82, 225-232.

Nugari, M.P., Salvadori, O., 2003. Biodeterioration control in cultural heritage: methods and products. In: Saiz-Jimenez, C. (Ed.), Molecular Biology and Cultura Heritage. Balkema, Lisse, pp. 233-242.

Ortega-Calvo, J.J., Sanchez-Castillo, P.M., Hernandez-Marine, M., Saiz-Jimenez, C. 1993. Isolation and characterization of epilithic chrorophytes and cyanobacteria from two cathedrals (Salamanca and Toledo). Nova Hedwigia 57, 239-253.

Pereira, T.A.R., 2008. Optimização das características de humedecimento e secagem de argamassas. Master thesis, Faculdade de Ciências e Tecnologia, Universidade Nova de Lisboa, Lisboa, Portugal.

Russel, A.D., Chopra, I., 1990. Understanding Antibacterial Action and Resistance. Horwood Ltd, Chichester.

Saiz-Jimenez, C., 1999. Biogeochemistry of weathering processes in monuments. Geomicrobiology Journal 16, 27-37.

Sert, H., Sümbül, H., Sterflinge, r K., 2007. A new specis of Capnobotryella from monument surfaces. Mycological Research 111, 1235-1241.

Silva, S., 2002. Caracterização de argamassas antigas - casos paradigmáticos. In: Cadernos edifícios 02- Revestimentos de paredes em edifícios antigos. LNEC, Lisboa.

Tiano, P., 1998. Biodeterioration of monumental rocks: decay mechanisms and control methods. Science and Technology for Cultural Heritage 7, 19-38.

Tomaselli, L., Lamenti, G., Tiano, P., Bosco, M., 2000. Biodiverity of photosynthetic micro-organisms dwelling on stone monuments. International Biodeterioration and Biodegradation 46, 251-258.

Wollenweider, R.A., 1979. A Manual on Methods for Measuring Primary Production in Aquatic Environments. Blackwell Scientific Publications, Oxford, UK.

Wu, D., Long, M., Zhou, J., Cai, W., Zhu, X., Chen, C., Wu, Y., 2009. Synthesis and characterization of self-cleaning cotton fabrics modified by $\mathrm{TiO}_{2}$ through a facile approach. Surface \& Coatings Technology 203, 3728-3733. 